\title{
Impact of service quality on Loyalty \& Mediating role of Trust: An empirical investigation of Restaurants
}

\author{
Fiza Amjad ${ }^{1}$, Sajjad Ahmad Baig ${ }^{1}$, Khalid Jamil ${ }^{2}$ Asma Amjad ${ }^{1}$ \\ ${ }^{1}$ Department of Management science, National Textile University Faisalabad \\ ${ }^{2}$ Lyallpur Business School GC University, Faisalabad \\ Fiza.amjad1@hotmail.com, sajjad.baig@hotmail.com, khalidjamil29@yahoo.com, Asma.amajd1@hotmail.com
}

\begin{abstract}
Study was conducted to investigate the relationship between service quality, trust and loyalty. The trust is mediating between service quality and loyalty. Service quality provided to the customer is responsibility of the restaurants. Using a convenient sampling data was collected from consumers. Service quality positively associated with trust and loyalty and trust is also positively linked with loyalty and mediates the relationship between service quality and loyalty according to our finding. This article helps the organizations to understand the importance of service quality provide and how consumers become loyal to the organization. Customer retention is higher and profitability is greater for the business over the long period of time.
\end{abstract}

Keywords: Service Quality, Loyalty, Trust, Restaurants

\section{Introduction}

In the present era where marketing conditions are changing constantly organizations must realize that the growing economic system with ever growing market not faced by them. So the end result is that every customer gained a new value. So the customer satisfaction is an element that encourage the use of services again and again but there is no guaranty that a satisfied customer make a purchase (Ribeiro Soriano, 2002). Marketers just focus on customer satisfaction not on increased customer satisfaction during 1980s and 1990s, but marketers realize with the passage of time that many customers who satisfies with the services not repurchase or reuse the products. When customer make repurchases with the same brands profitability raises so to maintain the position of the organizations loyalty of the customers is very important. Brand loyalty is a prerequisite for a firm's competitiveness and profitability (Reichheld, Markey Jr, \& Hopton, 2000). The importance of brand loyalty has been recognized in the marketing literature for at least three decades (Sheth \& Parvatiyar, 2002). In this connection, Aaker and Jacobson (1994) has discussed the role of loyalty in the brand equity process and has specifically noted that brand loyalty leads to certain marketing advantages like new customer, marketing cost reduce and grater trade leverage. Mostly organizations hold their customer as a competitive asset suggested by many investigations. At current time due to increase employment of women's outside the home and life style is being changed the restaurant industry is growing rapidly in Pakistan. On the other hand, increasing competition among the restaurant. Customer loyalty determine the important part in restaurant financial growth and competing the other organization and they keep their place in the market, Reichheld and Sasser (1990) study show the strong relation within customer and desertion to increasing the growth of the organization. Many researchers concluded that they keep their loyal customer as an aggressive asset. In reality the customer has many choices in the current competitive environment. This is the reason that customer chose their favorite options from available alternatives. The loyalty is considered as an important factor for the success of any restaurant in the present competitive environment. Another way we say that as the loyal customer increases the profitability also increases. Emerging a new chain of restaurant including sardines, Bandu khan, Khayyam etc. and their dedications to opening new branches in different cities is an indication of the problem. With increasing number of customer in the competitive environment there is no guarantee of profit rather than retaining the existing customers is most important than creating new ones. The aim of this study is to find the factors that contribute in the customer loyalty in the restaurant industry and provide guidelines to increase the loyalty build relationships with customers and enhance customer commitment.

Significance of the study: For the economic stability and development and growth of a country or nation loyalty is the important part this research study describe the importance of the loyalty and help the people to know the importance of the loyalty in different articles the loyalty is an important factor for developing, economic stability of a country or nation we analyze different sources and conclude these research describe 
the factor effecting on the loyalty and this research describe the importance of the loyalty and benefit of the build long term relationship with the customer and this research helps the marketer to develop and attract the loyal consumer and how they marketer develop the habit of loyalty in consumer.

\section{Literature Review}

Loyalty: Brand loyalty is a prerequisite for a firm's profitability and competitiveness (Reichheld et al., 2000). Desires every firms to have its brands with high customer loyalty. Unfortunately, all brands cannot attract loyalty is high. development and maintenance of consumer brand loyalty is placed at the heart of company brand loyalty place in the heart of companies plans in the highly competitive environment with high uncertainty and more product differentiations (Fournier \& Yao, 1997). The importance of brand loyalty has been recognized in the marketing literature for at least three decades (Sheth \& Parvatiyar, 2002). In this connection, Aaker and Jacobson (1994) has discussed the role of loyalty in the brand equity process and has specifically noted that brand loyalty leads to certain marketing advantages like marketing expense are decreasing, increased customers and high leverage of trade. Dick and Basu (1994) suggest other loyaltyrelated marketing advantages, such as favorable word of mouth and greater resistance among loyal consumers to competitive strategies. Yet despite the clear managerial relevance of brand loyalty, conceptual and empirical gaps remain. Specifically, with some exceptions (Zeithaml, Berry, \& Parasuraman, 1996), our conceptualizations of brand loyalty emphasize only the behavioral dimension of that concept and not considering its behavioral dimensions and its relationship with other variables at the consumer and market levels. Brand loyalty is a consumer's preference to buy a single brand name in a product class; it is a result of the perceived quality of the brand and not its price (Zehir, Şahin, Kitapçı, \& Özşahin, 2011). Brand loyalty may be indicated by brand attitudes and habit (Rauyruen \& Miller, 2007), it is also differentiate from either attitudes. Customer Satisfaction with the Brand performance can be expressed in term of brand loyalty.

Service quality: The service quality examines carefully that perception of consumer about the service elements like physical environment, interaction quality and the quality of outcome. Service quality dimensions (reliability, assurance, responsiveness, empathy) are basses to evaluate the service elements and tangibles. Zeithaml, Berry, and Parasuraman (1988) define service quality as global judgment or attitude relation to the overall excellence or superiority of the service 'it has been also defining the service quality as "the degree of discrepancy between customers' normative expectations for the service and their perceptions of the service performance". Grönroos (2001) perceived judgment of service quality of any organization and resulting evaluation process is start where customer compares their expectations with the service they perceive to have received. Cronin Jr and Taylor (1992) suggested that the implication and conceptualization of service quality was not sufficient and cited adequate marketing literature (Bolton \& Drew, 1991) supporting performance-based simple measures of service quality. Zeithaml et al. (1996) the customers' behavioral intention in service develop the comprehensive, and multi-dimensional framework. Initially this framework adjusting four main types like purchase intention, price sensitivity word of mouth and complaining behavior.

Trust: Gundlach and Murphy (1993) contend that "the variable most universally accepted trust as a basis of any human interaction". Moorman, Deshpande, and Zaltman (1993), give a Definition of trust that the degree of willingness that the consumer trust on the ability of brand that it perform its stated function ".This definition has two general approaches to trust in the literature (Kennedy, Ferrell, \& LeClair, 2001). First, dimension as the trust viewed as a belief, sentiment, or expectation relate to the partner's trustworthiness that are concluded from the other partner expertise, reliability, or expectation about an exchange partner's trustworthiness that results from the partner's expertise, reliability, or intentionality. Second aspect of trust Viewed as behavioral dimension indicate that rely on a partner and unreliability on the part of trustee. Doney and Cannon (1997) also focus that the notion of trust is related only in condition of uncertainty when small difference are $\mathrm{n}$ brands. Especially in environment of criticism they can rely on trusted brands and reduce uncertainty. Doney and Cannon (1997) argue that the trust construction involves a "calculation process" depend on the brand ability of an object to continue to fulfill its responsibility and the estimate of a reward against the estimated cost stay along in relationship. On the other hand, Doney and Cannon (1997) argue that the trust influence the firm to act in the best interest of their customers based on share values and goals. Thus, beliefs about important facets of trust like reliability, safety, and honesty that people incorporate in their operationalization of trust, as we discuss latter. So, we consciously consider of any brand trust as it 
involves process. Customer Trust generally develops through the following five stages: (1) enlargement, (2) suspension, (3) responsiveness, (4) commitment, and (5) investigation, (Roberts, Varki, \& Brodie, 2003). Customer trust on a certain brand is the determinant of the future purchase intentions of a customer and it is an important factor to maintain a profitable relationship with customer (Lagace \& Marshall, 1994).

Service quality and trust: According to Delgado-Ballester and Luis Munuera-Alemán (2001) usually customer choose a brand that they believes more reliable and more trustworthiness. Another researcher Auka (2012) argue that consumer perceive service quality of the brand in term of the appraisal of overall service quality. He argues that the service quality as it is a difference between the expectation of consumer about the service quality and how customer perceive the performance of service quality. Some other researcher like McQuitty, Finn, and Wiley (2000) explain that there is some differences between expectations and perceived performance that is the best indicator of customer satisfaction that results in level of trust among customers, He give an example that when consumer makes purchase occasionally different brands they may be switch these brands because they are not completely satisfied with the brand and have more expectations with other brands. Auka (2012) suggested that service quality is sufficient when the consumer perception about brands equal or exceed the consumer perception. Service quality means judgment of the service superiority at certain attribute level of service quality.

Trust and Loyalty: "It is no longer sufficient to concentrate only on customer satisfaction; the next step is loyalty" a definition given by (Anderson, Rungtusanatham, \& Schroeder, 1994). It has been found that trust has positive effect on loyalty of customer means if consumers have trust on company product and services in return they will be more loyal toward that organization research was conducted in Bangladesh among the consumers of telecommunication sectors they argued that if consumers will be more confident they will be more loyal (Hafeez \& Muhammad, 2012). Horppu, Kuivalainen, Tarkiainen, and Ellonen (2008) The research results supported the hypothesis and suggesting that trust on the web site level are bases of web site loyalty. Yet, results also indicated that brand-level experiences affect online trust and loyalty differently relies on the customer's connection with the brand. Van Vuuren, Roberts-Lombard, and Van Tonder (2012) research study reveals in an optometric practice environments consumer trust has significant high correlation with consumer loyalty if service providers provide their maximum efforts and intentions toward consumers they have more confident about an organization services and more loyal. Another researcher found the positive relationship between trust and loyalty they claimed that trust has positive influence on loyalty of consumers regard to organizations if one organizations developed their trust to engaged in Corporate Social responsibility (Social Identity) that will results in consumers loyalty about organization (Nguyen, Leclerc, \& LeBlanc, 2013). Morgan and Hunt (1994) explain trust as if the exchange partner had reliability and the other party has confidence on the exchange partner.

According to Sharma and Patterson (1999) the willingness of one partner to rely on the exchange partner is that the one party has confidence. The activities of the exchanging partner will beneficial for one partner carefully argued by Akbar and Parvez (2009). According to Doney and Cannon (1997) the related parties that have using the cost-benefit relationship concerned with customer meet the responsibilities toward the customer. Attitude and Customer behavior two things contribute in customer loyalty. Intention to purchase or Purchase additional services and products and the repurchase intention of customer to purchase the products of the same company represent this notion represent the customer attitude, the willingness of customer to recommend the others to company that demonstrate the customer commitment to the company by showing the resistance to switching behavior towards the competitors and agreed to pay higher prices for products (Zeithaml et al., 1996). Other side the loyalty of customer represents the actual and repeat purchases of same or different goods and services from the same company advice other customers to purchase he products if the same company and give the probability of choice for the brand for a long time (Mokhtar, Maiyaki, \& Mohd Noor, 2011). Grönroos (1984) conducted an empirical investigation which state that customer trust enhances the customer loyalty, by testing he found that customer trust has directly influence loyalty. The customers have trust on organization that results in loyalty.

Oliver, Rust, and Varki (1997) in future defined loyalty as a "deeply held commitment to rebury or patronize a preferred product or service consistently, in which causing repetitive same product or same brand-set purchasing, but some instead situation effect on the market efforts and switching behavior due to this despite 
influence. Many studies describe the advantages of the loyalty. Zeithaml et al. (1996) service quality describes as "increased repurchase volume, better acquisition rates from positive word-of-mouth communication and lower sensitivity when the price is increases .in which conceder the effect of service quality on loyalty. Some previous research indicates that service quality impact on the consumer loyalty. Through the corporate and reliability on the brand ( $\mathrm{Hu}$, Kandampully, \& Juwaheer, 2009). Some other studies indicate that service quality directly impact customer loyalty due to the presence of customer image or the reliability of the customer. Defining loyalty is a challenging job for researchers, because there is no precise conceptualization and there is verification exist in contract. Study suggest that frequent use and satisfaction with a product or service are usually linked with loyalty. Zeithaml et al. (1996) describe service quality as "increased repurchase volume, better acquisition rates to increases the positive word of mouth related this restaurant and price sensitivity is higher. Some past researches shows that loyalty effected by service quality (Cheng, Lai, \& Yeung, 2008). Some other studies indicate that service quality directly impact customer loyalty due to the presence of customer image or customer satisfaction. Defining loyalty is a challenging job for researchers, because there is no precise conceptualization and there is verification exist in contract. Study suggests that frequent use and satisfaction with a product or service are usually associated with loyalty.

Mediating Role of Trust: After review prior studies on service quality loyalty and trust is can be seen as mediator between service quality and loyalty with respect to mediating role of trust, they insist the trust play role as mediator or interviewing if restaurant retain the five characteristic of service quality Parasuraman and Grewal (2000) identified five elements of service quality (viz. reliability, responsiveness, assurance, empathy, and tangibles)Consequent result of these five elements of service quality in loyalty social identity in loyalty on performing essential part of mediating variable trust Furthermore loyalty is not only effected by integral assessment of company they outside power of customer can also influence on organization like outside activities advertisement promotions personnel selling publicity public rationing word of mouth etc. Trust level is somewhat mediate of customer due to service quality attribution on the support aim and agreement consumer purchase decision influence by company side as a result of loyalty. the loyalty in which mediated by trust. Organizations side to influence the consumers purchase decisions as results of loyalty that is mediated by trust eventually if customer trust on the loyalty generate in form of repurchasing positive word of mouth etc. Stakeholder-driven attributions effect customer repurchasing and spared the positive word of mouth an indirectly the effect of trust as mediator trust is direct effect on customer commitment and loyalty then indirectly effect on price tolerance. Louis and Lombart (2010) explored the influence of service quality of a product on consumer's trust on the restaurant which leads to the development of consumer 'loyalty with the restaurant so, they studied the trust is meditating on restaurant service quality and loyalty relationship. And this service quality is the base to generate trust on the restaurant and this trust and satisfaction develops a consumer loyalty with the restaurant. Service quality of restaurant has strong influence on consumer's mind.

\section{Methodology}

Measures and Sampling Procedure: A self-administered questionnaire was chosen as a research instrument to gather the primary data of service quality, trust, loyalty in restaurant. Constructs in our study developed by using measurement scale adopted from prior studies.

Service quality: In which we use the 22 items of service quality and this items is measure using seven point Likert scale with anchors strongly disagree $(=1)$ strongly agree $(=7)$.

Loyalty: we use the 7 items of loyalty and these items is measure using seven point Likert scale with anchors strongly disagree $(=1)$ strongly agree $(=7)$.

Trust: Trust is used 4 items and this items is measured using five Likert scale with anchors strongly disagree $(=1)$ strongly agree ( $=5)$ and this items is used by Morgan and Hunt (1994), "The Commitment-Trust Theory of Relationship Marketing , Journal of Marketing 58, 20-38) from previous studies.

Sample: A total of 150 questionnaires were distributed to use restaurant in Faisalabad. Convenient sampling technique increase the reliability of the data was adopted convenient sampling. In this research study, the 
questionnaires were distributed directly to the respondents and the research collected completed questionnaires. And the data was collected for this research from the student of National Textile University Faisalabad different department (MBA, Textile, IT, Applied Sciences, Fashion Designing).

Sample Characteristics: Respondents sample selected for this study was individual customers of restaurant sector in Faisalabad. There are some demographic characteristics of these individual respondents, in which included statistical values such as frequency and percentages of different demographic characteristics of respondents. Percentages: 1) Gender, 2) Occupation, 2) Age, 4) income 5) Education, 6) restaurant.

\section{Results}

Table 1: Data analysis

\begin{tabular}{|c|c|c|c|c|c|}
\hline $\begin{array}{l}\text { Demographic } \\
\text { variables }\end{array}$ & Frequency & $\begin{array}{l}\text { Percentage } \\
\%\end{array}$ & $\begin{array}{l}\text { Demographic } \\
\text { Variables }\end{array}$ & Frequency & $\begin{array}{l}\text { Percentage } \\
\%\end{array}$ \\
\hline 1. Gender & & & Bachelor & 44 & 29.9 \\
\hline Male & 63 & 42.9 & Masters & 68 & 46.3 \\
\hline Female & 84 & 57.1 & Other & 34 & 23.1 \\
\hline 2.Income & & & 5.0ccopation & & \\
\hline Less than 10,000 & 31 & 21.1 & Student & 61 & 41.5 \\
\hline $10,000-30,000$ & 28 & 19.0 & Job holder & 85 & 57.8 \\
\hline $31,000-50,000$ & 40 & 27.2 & Other & 1 & .7 \\
\hline $51,000-80,000$ & 29 & 19.7 & 6.Brands & & \\
\hline Above 80,000 & 19 & 12.9 & the dynasty & 23 & 15.6 \\
\hline 3.Age & & & Lasania & 10 & 6.8 \\
\hline $10-20$ & 5 & .7 & Sardines & 11 & 7.5 \\
\hline $21-25$ & 85 & 57.8 & Quilim & 12 & 8.2 \\
\hline $26-30$ & 40 & 27.2 & silver spoon & 21 & 14.3 \\
\hline $31-35$ & 16 & 10.9 & Tabbaq & 15 & 10.2 \\
\hline $36-40$ & 5 & 3.4 & al-nakhal & 18 & 12.2 \\
\hline Above 40 & 0 & 0 & Khayyam & 14 & 9.5 \\
\hline 4.Qualification & & & Bandu khan & 12 & 8.2 \\
\hline Intermediate & 1 & .7 & Others & 11 & 7.5 \\
\hline
\end{tabular}

According this statistical value $42.9 \%$ male and remaining $57.1 \%$ is female in this sample in occupation $42.5 \%$ is student and $57.5 \%$ is job holder. As for as age related $.7 \%$ fall under age $10-20$ years and $57.8 \%$ fall under age group $21-25$ years and $27.2 \%$ under age $26-30$ years and $10 \%$ fall the age $31-35$ and $3 \%$ in the age of 36-40 intermediate are $.7 \%$ in this sample, bachelor degree holder are up to $29.9 \%$, large number of respondent $46.3 \%$ holds master degree in this sample and other degree holder are only $23.1 \%$, most of the respondent $27.2 \%$ income is $31000-50000$ and $40 \%$ respondent below the income $31000-50000$ and $31 \%$ above the income 31000-50000 at the end 15.6\% respondent in dynasty restaurant $6.8 \%$ in Lasania $7.5 \%$ sardines $8.2 \%$ quilim and $14.3 \%$ silver spoon $10.2 \%$ in Tabbaq $12.2 \%$ in al nakhal $9.5 \%$ Khayyam $8.2 \%$ bandu khan $7.5 \%$ include the other restaurant response. 
Table 2: Regression analysis

\begin{tabular}{llll}
\hline Service & R square & $\begin{array}{l}\text { Loyalty } \\
\text { Significance }\end{array}$ & Beta \\
\hline quality & .058 & .003 & .241 \\
\hline
\end{tabular}

Regression results of loyalty as dependent variable and service quality as independent variable shows positive and significant relation between these two variables at $(\mathrm{p}<.001)$ significance.

A. Predictor: (constant) service quality

B. Dependent Variable: loyalty

C. Significance at $<0.01$

D. $\mathrm{N}=150$

Results show that the model significant at $(\mathrm{p}<0.01)$. In which the value of R-Square show the positive rate of changed by independent variable $(0.058)$ to dependent variable appropriate at $(.241,0.00)$. R-Square value shows the variation in loyalty (5.8\%) due to change in service quality.

Table 3: Summary

\begin{tabular}{llll}
\hline Service & R square & $\begin{array}{l}\text { Trust } \\
\text { Significance }\end{array}$ & Beta \\
\hline Quality & .027 & .049 & .163 \\
\hline
\end{tabular}

A. Predictor: (constant) service quality

B. Dependent Variable: Trust

C. Significance at $<0.01$ D. $N=150$

Table-1.4 indications model tested significant at $(\mathrm{p}<0.01)$. this results show that the value of R-Square show they positive rate of change by independent variable (0.027) to dependent veritable at (0.163) in which the RSquare values describe and show the variation in trust (2.7\%)due to change in service quality. $o$

\section{Summary}

\section{Loyalty}

\begin{tabular}{llll}
\hline & R square & Significance & Beta \\
\hline Trust & .367 & .000 & .606 \\
\hline
\end{tabular}

Regression results of brand trust as independent variable and loyalty as dependent variable shows significant relation between these two variables at $(\mathrm{p}<.001)$ significance.
A. Predictor: (constant) Trust
B. Dependent Variable: Loyalty
C. Significance at $<0.01$
D. $\mathrm{N}=150$

Table 1.5 significant at $(\mathrm{p}<0.01)$ tested the show the modal in which this table the value of $\mathrm{R}$-Square show the positive rate of change in dependent variable appropriate at $(0.606)$ by independent variable (0.367) and the value of R-Square show the variation in loyalty (36.7\%) due to change in trust.

Table 4: Regression analysis

\begin{tabular}{lllll}
\hline & & Trust & & Loyalty \\
\hline Predictors & $\mathrm{B}$ & $\mathrm{R}^{2}$ & $\mathrm{~B}$ & $\mathrm{R}^{2}$ \\
Service quality & $.163^{*}$ & .027 & $.241^{* *}$ & .058 \\
\hline
\end{tabular}

Mediation Analysis: This study is a first attempt to examine the mediating effect trust between service quality and loyalty in restaurant. Part of this study the four hypothesis show that H4: trust mediates the relationship of service quality and loyalty. Regression technique was used to test this hypothesis which was 
recommended by Baron and Kenny (1986). According to Baron and Kenny (1986), following condition should be fulfilled. (1) The relationship between independent variable and mediating variable should be significant; (2) the relationship between mediating variable and dependent variable should also be significant. (3) The relationship between independent and dependent variables should also be significant. When these three conditions are fulfilled then researcher goes for further analysis. Perfect mediation is when the independent variable has direct effect on dependent variable i.e. $\left(\Delta \mathrm{R}^{2}=.00\right)$ and independent variable should also have $(\beta \neq$ sig).

Table 5: Mediation analysis

\begin{tabular}{llll}
\hline Predictors & $\mathbf{B}$ & $\begin{array}{l}\text { Loyalty } \\
\mathbf{R}^{\mathbf{2}}\end{array}$ & $\mathbf{\Delta R}^{\mathbf{2}}$ \\
\hline Mediation Analysis & & \\
Step 1 & & & \\
Trust & & .367 & $.021^{*}$ \\
Step 2 & & .388 & \\
Service quality & .146 &
\end{tabular}

A. Predictor: (Constant), Trust

B. Predictors: (Constant), Trust, service quality

C. Dependent Variable: Loyalty

D. Significance at $<0.01$

$\mathrm{N}=150$

The table describe the trust as mediates the relationship between service quality and loyalty in which they fulfill the both condition of mediation which $(\beta \neq \operatorname{sig})$ and $\left(\Delta \mathrm{R}^{2}=.00\right)$ so trust play the mediate role between service quality and loyalty in which $\left(\Delta \mathrm{R}^{2}=.021, \mathrm{p}<0.01\right)$ and $(\beta=.146, \mathrm{p}<0.01)$ as explained by (Baron \& Kenny, 1986). The value of $\mathrm{R}$ - Square describe that (14.6\%) change in dependent variables due to independent variables. The H4: trust mediates the relationship of service quality and loyalty.

\section{Conclusion}

This research study examined the impact of service quality on loyalty: the mediating role of trust. This is a study of restaurant industry in Faisalabad. The main objectives of this study are to discover the mediating role of trust between service quality and loyalty. For this study, researcher was considered only about restaurant industry. Following categories of restaurant were selected:

1) the dynasty 2) Lasania B 3) Quilim, 4) silver spoon 5) Tabbaq 6) Al-nakhal 7) Khayyam 8) Bandu khan and others. The restaurant industry in Pakistan is contributing a lot in economy, it is a highly important segment that plays a pivotal role in financial sector of Pakistan. Due to high level of competition in restaurant sector, restaurants have to be more innovative and more aggressive in developing their product in order to meet the demand of target customer, and to develop trust and customer's attachment with restaurants. The primary data collection method was used questionnaire used this is self-administered questionnaire used for collecting data from 150 customers of different restaurant uses. Convenient sampling technique used for sample size. Independent variable is service quality, loyalty is a dependent variable, and trust is mediating variable according to theoretical framework of this study. All these variables were measured by using different point Likert scale which was adopted from previous literature. The Statistical techniques descriptive analysis, Cronbach alpha, correlation analysis, and regression analysis had been used to explore the relationship between variables. Significant results show that the positive and linear relationship among all study variables, the significant level of ( $p<$ value) for all study variables is significant at $(p=0.01)$ ** level 2 tailed. Results explore that service quality have positive and significant impact on trust and customer loyalty. When we provide the good service quality to customer developed the trust related this product and then loyal to the restaurant. When the trust is developing they restaurant take advantage over there competitor in which all relation between variables is significant and positive relation with each other. 


\section{References}

Aaker, D. A. \& Jacobson, R. (1994). The financial information content of perceived quality. Journal of Marketing Research, 3, 191-201.

Akbar, M. M. \& Parvez, N. (2009). Impact of service quality, trust, and customer satisfaction on customers loyalty. ABAC Journal, 29(1).

Anderson, J. C., Rungtusanatham, M. \& Schroeder, R. G. (1994). A theory of quality management underlying the Deming management method. Academy of management Review, 19(3), 472-509.

Auka, D. 0. (2012). Service quality, satisfaction, perceived value and loyalty among customers in commercial banking in Nakuru Municipality, Kenya. African Journal of Marketing Management, 4(5), 185-203.

Baron, R. M. \& Kenny, D. A. (1986). The moderator-mediator variable distinction in social psychological research: Conceptual, strategic, and statistical considerations. Journal of personality and social psychology, 51(6), 1173.

Bolton, R. N. \& Drew, J. H. (1991). A multistage model of customers' assessments of service quality and value. Journal of Consumer Research, 17(4), 375-384.

Cheng, T. E., Lai, L. \& Yeung, A. C. (2008). The driving forces of customer loyalty: a study of internet service providers in Hong Kong. International Journal of E-Business Research, 4(4), 26.

Cronin Jr, J. J. \& Taylor, S. A. (1992). Measuring service quality: a reexamination and extension. The Journal of Marketing, 3, 55-68.

Delgado-Ballester, E. \& Luis Munuera-Alemán, J. (2001). Brand trust in the context of consumer loyalty. European Journal of Marketing, 35(11/12), 1238-1258.

Dick, A. S. \& Basu, K. (1994). Customer loyalty: toward an integrated conceptual framework. Journal of the academy of marketing Science, 22(2), 99-113.

Doney, P. M. \& Cannon, J. P. (1997). An examination of the nature of trust in buyer-seller relationships. The Journal of Marketing, 2, 35-51.

Fournier, S. \& Yao, J. L. (1997). Reviving brand loyalty: A reconceptualization within the framework of consumer-brand relationships. International Journal of Research in Marketing, 14(5), 451-472.

Grönroos, C. (1984). A service quality model and its marketing implications. European Journal of Marketing, $18(4), 36-44$.

Grönroos, C. (2001). The perceived service quality concept-a mistake? Managing Service Quality: An International Journal, 11(3), 150-152.

Gundlach, G. T. \& Murphy, P. E. (1993). Ethical and legal foundations of relational marketing exchanges. The Journal of Marketing, 3, 35-46.

Hafeez, S. \& Muhammad, B. (2012). The Impact of Service Quality, Customer Satisfaction and Loyalty Programs on Customer's Loyalty: Evidence from Banking Sector of Pakistan. International Journal of Business and Social Science, 3(16).

Horppu, M., Kuivalainen, O., Tarkiainen, A. \& Ellonen, H. K. (2008). Online satisfaction, trust and loyalty, and the impact of the offline parent brand. Journal of product \& brand management, 17(6), 403-413.

Hu, H. H., Kandampully, J. \& Juwaheer, T. D. (2009). Relationships and impacts of service quality, perceived value, customer satisfaction, and image: an empirical study. The Service Industries Journal, 29(2), 111-125.

Kennedy, M. S., Ferrell, L. K. \& LeClair, D. T. (2001). Consumers' trust of salesperson and manufacturer: an empirical study. Journal of Business research, 51(1), 73-86.

Louis, D. \& Lombart, C. (2010). Impact of brand personality on three major relational consequences (trust, attachment, and commitment to the brand). Journal of product \& brand management, 19(2), 114-130.

McQuitty, S., Finn, A. \& Wiley, J. B. (2000). Systematically varying consumer satisfaction and its implications for product choice. Academy of Marketing Science Review, 2(1).

Mokhtar, S., Maiyaki, A. \& Mohd Noor, N. (2011). The relationship between service quality and satisfaction on customer loyalty in Malaysian mobile communication industry. School of Doctoral Studies (European Union) Journal, 2(3), 32-38.

Moorman, C., Deshpande, R. \& Zaltman, G. (1993). Factors affecting trust in market research relationships. The Journal of Marketing, 4, 81-101.

Morgan, R. M. \& Hunt, S. D. (1994). The commitment-trust theory of relationship marketing. The Journal of Marketing, 3, 20-38. 
Nguyen, N., Leclerc, A. \& LeBlanc, G. (2013). The mediating role of customer trust on customer loyalty. Journal of service science and management, 6(01), 96.

Oliver, R. L., Rust, R. T. \& Varki, S. (1997). Customer delight: foundations, findings, and managerial insight. Journal of retailing, 73(3), 311-336.

Parasuraman, A. \& Grewal, D. (2000). The impact of technology on the quality-value-loyalty chain: a research agenda. Journal of the academy of marketing Science, 28(1), 168-174.

Rauyruen, P. \& Miller, K. E. (2007). Relationship quality as a predictor of B2B customer loyalty. Journal of Business research, 60(1), 21-31.

Reichheld, F. F., Markey Jr, R. G. \& Hopton, C. (2000). The loyalty effect-the relationship between loyalty and profits. European business journal, 12(3), 134.

Reichheld, F. F. \& Sasser, J. W. (1990). Zero defections: Quality comes to services. Harvard business review, 68(5), 105-111.

Ribeiro Soriano, D. (2002). Customers' expectations factors in restaurants: The situation in Spain. International Journal of Quality \& Reliability Management, 19(8/9), 1055-1067.

Roberts, K., Varki, S. \& Brodie, R. (2003). Measuring the quality of relationships in consumer services: an empirical study. European Journal of Marketing, 37(1/2), 169-196.

Sharma, N. \& Patterson, P. G. (1999). The impact of communication effectiveness and service quality on relationship commitment in consumer, professional services. Journal of Services Marketing, 13(2), 151-170.

Sheth, J. N. \& Parvatiyar, A. (2002). Evolving relationship marketing into a discipline. Journal of relationship marketing, 1(1), 3-16.

Van Vuuren, T., Roberts-Lombard, M. \& Van Tonder, E. (2012). Customer satisfaction, trust and commitment as predictors of customer loyalty within an optometric practice environment. Southern African Business Review, 16(3), 81-96.

Zehir, C., Şahin, A., Kitapçı, H. \& Özşahin, M. (2011). The effects of brand communication and service quality in building brand loyalty through brand trust; the empirical research on global brands. Procedia-Social and Behavioral Sciences, 24, 1218-1231.

Zeithaml, V. A., Berry, L. L. \& Parasuraman, A. (1988). Communication and control processes in the delivery of service quality. The Journal of Marketing, 2, 35-48.

Zeithaml, V. A., Berry, L. L. \& Parasuraman, A. (1996). The behavioral consequences of service quality. The Journal of Marketing, 3, 31-46. 